\title{
Do Genetic Variants of the Renin-Angiotensin System Predict Blood Pressure Response to Renin-Angiotensin System-Blocking Drugs? A Systematic Review of Pharmacogenomics in the Renin-Angiotensin System
}

\author{
Tadashi Konoshita • \\ the Genomic Disease Outcome Consortium (G-DOC) \\ Study Investigators \\ Published online: 13 May 2011 \\ (C) The Author(s) 2011. This article is published with open access at Springerlink.com
}

\begin{abstract}
The concept of "pharmacogenomics" or "pharmacogenetics" promises to offer the ultimate in personalized medicine, and the renin-angiotensin system (RAS) is one of the most plausible candidates for the application of this approach in the area of hypertension. For the past two decades, genetic variants of the RAS have been tested for association with blood pressure response, but the results have been inconsistent. The problems have been attributed to many issues, but the most fundamental concern is thought to be the statistical power of the studies. Therefore, we have tried to put together a new systematic review using a database search including only recent reports with adequate numbers of subjects, and 11 reports were identified. From the results, we were able to draw conclusions with nearly consistent findings that the conventional genetic variants of the system (i.e., the ACE I/D, AGT M235T, AT1 A1166C, and AT2 variant) are not associated with antihypertensive effects by RAS blockade, at least by one individual SNP. By contrast, significant associations have been reported (by one report each) for AGT rs7079, AT1 haplotype, REN, and ACE2. For these variants, further evaluations and confirmation are anticipated.
\end{abstract}

Keywords Renin · Renin-angiotensin system · RAS · Genetic variant Polymorphism $\cdot$ Pharmacogenomics . Pharmacogenetics · Angiotensin-converting enzyme inhibitor - ACEI - Angiotensin receptor blocker - ARB . Direct renin inhibitor Blood pressure response $\cdot$ Responder

T. Konoshita $(\square)$

Third Department of Internal Medicine,

Fukui University School of Medicine,

23-3, Matsuokashimoaizuki, Eiheiji,

Fukui 910-1193, Japan

e-mail: konosita@u-fukui.ac.jp

\section{Introduction}

One of the most intriguing issues for the next stage of the postgenome era is "pharmacogenomics" or "pharmacogenetics," a concept that offers the ultimate personalized medicine, by which favorable effects of medications are maximized and adverse effects are minimized, compared with conventional "trial and error" prescribing. This type of "tailored" medicine is coming to be expected. In the area of hypertension, the renin-angiotensin system (RAS) is the most plausible candidate for pharmacogenomics. The RAS plays major roles in blood pressure regulation and electrolyte metabolism [1] and also has pivotal roles in cardiovascular [2], renal [3], and metabolic conditions [4]. During almost two decades, genetic variants of this system have been tested for their association with hypertension and cardiovascular conditions. Conventionally (with controversy), angiotensin-converting enzyme (ACE) insertion/deletion polymorphism has been associated with ischemic heart disease [5] and the development of endstage renal diseases [6-9]. Angiotensinogen (AGT) M235T has been associated with the development of hypertension [10, 11]. Angiotensin II type 1 receptor (AT1) A1166C has been associated with the development of hypertension and ischemic heart disease $[12,13]$. Recently, a number of largescale prospective studies have proven that RAS blockade has favorable effects on cardiovascular and renal conditions [1419]. However, the association between genetic variants of the RAS and the effects of angiotensin II receptor blockers (ARBs) and ACE inhibitors was still unclear in a 2007 systematic review by Farahani et al. [20]. The uncertainty has been attributed to many issues, but the most fundamental concern is thought to be lack of statistical power. Therefore, we have tried to produce an updated systematic review, using 
a database search for the latest reports with adequate numbers of subjects.

\section{Identification of Studies}

This review focuses on the genetic variants of the RAS and blood pressure response to RAS blockade. Studies were identified by an initial PubMed search with condition 1 (("pharmacogenetics"[All Fields] OR "pharmacogenomics"[All Fields]) AND ("renin"[All Fields] OR “ACE”[All Fields] OR "angiotensinogen"[All Fields])) or condition 2 (("genetic variant"[All Fields] OR "polymorphism"[All Fields]) AND ("blood pressure response"[All Fields] OR ("blood pressure responder"[All Fields]) AND “angiotensin"[All Fields]). Condition 1 identified 136 studies, and condition 2 found 52. From these studies (which included reviews), studies were identified that evaluated the genes for ACE, AGT, AT1, angiotensin II type 2 receptor (AT2), renin (REN), and angiotensin-converting enzyme 2 (ACE2). The evaluated RAS-blocking drugs were ARBs and ACE inhibitors.

Practical clinical implications require detection of a difference in diastolic blood pressure between groups of almost $5 \mathrm{~mm} \mathrm{Hg}$. Thus, we calculated the necessary sample size of the study, assuming a standard deviation for the diastolic blood pressure of $10 \mathrm{~mm} \mathrm{Hg}$ by a bilateral paired Student's $t$-test with protection against type I error of $5 \%$ and $80 \%$ of power, and determined that a study required 200 subjects in total to have adequate statistical power. We therefore adopted studies with about 200 or more subjects for assessment, finding the 11 studies shown in Table 1 . Three of these studies tested ARBs and eight looked at ACE inhibitors.

\section{ACE Gene Variant}

The most evaluated gene in pharmacogenomics studies for the RAS is ACE, especially the insertion and deletion (I/D) genetic variant of intron 16 . The first report, from Rigat et al. [21], indicated that serum ACE concentration differs according to the I/D allele numbers, and this phenomenon has been reconfirmed in many studies. Accordingly, the I/D variant is one of the most plausible candidates for pharmacogenomic RAS blockade intervention. Indeed, early studies showed significant differences of blood pressure reduction among the variants. A greater reduction by enalaprilat in II genotype compared with DD genotype was reported in 23 normotensive men [22], and a greater reduction by irbesartan in $\mathrm{D}$ allele compared with I allele was reported in 43 hypertensive patients [23]. However, as shown in Table 1, recent relatively well-powered studies have almost consistently shown no difference in blood pressure reduction in ACE genotypes (mainly the $\mathrm{I} / \mathrm{D}$ variant) by ARBs $[24 \bullet \bullet, 25 \bullet \cdot, 26]$ or ACE inhibitors [2729]. Thus, we may conclude that the ACE I/D gene variant is not associated with antihypertensive effects from RAS blockade.

\section{AGT Gene Variant}

Another of the most evaluated genes in pharmacogenomics studies for the RAS is AGT, especially the M235T genetic variant. Evidence of genetic linkage between the AGT gene and hypertension, as well as association of AGT with the disease, has been observed, and significant differences in plasma concentrations of angiotensinogen were found among hypertensive subjects with different AGT genotypes [10]. Thus, the AGT variant is one of the most plausible candidates for pharmacogenomic RAS blockade intervention. Although one previous study of 125 cases reported that M235T was associated with lowered blood pressure in response to ACE inhibitors [30], the recent relatively well-powered studies in Table 1 almost consistently observed no difference in blood pressure reduction with M235T and A-6G (which is thought to be in linkage disequilibrium with M235T) by ARBs [24••, $25 \bullet \cdot, 26]$ or ACE inhibitors [27, 31]. Thus, it seems that we can conclude that the conventional AGT gene variant, M235T, is not associated with antihypertensive effects of RAS blockade.

$\mathrm{Su}$ et al. have reported that M235T is not associated with the antihypertensive effects of benazepril, but a new single nucleotide polymorphism (SNP), rs7079 (C11537A), is associated with blood pressure reduction in response to benazepril [32]. As this is the only report regarding rs7079 (C11537A) of AGT, further evaluations are expected.

\section{AT1 Gene Variant}

The AT1 genetic variant, especially A1166C, also has been widely evaluated as a candidate for pharmacogenomic study for the RAS. This variant originally was associated with hypertension and ischemic heart disease [12, 13]. Unlike ACE and AGT, it has no evident intermediate phenotype, such as blood concentrations, but the AT1 variant is nevertheless one of the most plausible pharmacogenomic candidates for RAS blockade intervention, as a major component of the system. As shown in the Table 1, recent relatively well-powered studies have consistently found no difference for $\mathrm{A} 1166 \mathrm{C}$ in blood pressure reduction by ARBs $[24 \bullet \bullet, 25 \bullet \bullet, 26]$ and ACE inhibitors $[27,33,34]$. Thus, we may conclude that the conventional AT1 gene variant, A1166C, is not associated with the antihypertensive effects of RAS blockade. 
Table 1 Pharmacogenomics in the renin-angiotensin system (RAS): Studies of blood pressure response to RAS blockade among genetic variants

\begin{tabular}{|c|c|c|c|c|c|c|c|c|}
\hline Study & Year & Area & Ethnicity & $\begin{array}{l}\text { Patients, } \\
N\end{array}$ & $\begin{array}{l}\text { Drug } \\
\text { class }\end{array}$ & Drug & $\begin{array}{l}\text { Genetic variant of } \\
\text { the RAS }\end{array}$ & $\begin{array}{l}\text { Significant } \\
\text { difference? }\end{array}$ \\
\hline $\begin{array}{l}\text { Nordestgaard et } \\
\text { al. }[24 \bullet \bullet]\end{array}$ & 2010 & Scandinavia & $\begin{array}{l}\text { White } \\
(92 \%)\end{array}$ & 1,774 & $\mathrm{ARB}$ & Losartan & $\begin{array}{l}\text { ACE (I/D) } \\
\text { AGT (M235T) } \\
\text { AT1 (A1166C) }\end{array}$ & $\begin{array}{l}\text { No } \\
\text { No } \\
\text { No }\end{array}$ \\
\hline $\begin{array}{l}\text { Konoshita et al. } \\
{[25 \bullet \cdot]}\end{array}$ & 2009 & Japan & $\begin{array}{l}\text { Japanese } \\
(100 \%)\end{array}$ & 231 & $\mathrm{ARB}$ & Valsartan & $\begin{array}{l}\text { ACE (I/D) } \\
\text { AGT (M235T) } \\
\text { AT1 (A1166C) } \\
\text { AT2 (C3123A) } \\
\text { REN (C-5312T) }\end{array}$ & $\begin{array}{l}\text { No } \\
\text { No } \\
\text { No } \\
\text { No } \\
\text { Yes }\end{array}$ \\
\hline Redon et al. [26] & 2005 & Spain & $\begin{array}{l}\text { Spanish } \\
\quad(100 \%) ?\end{array}$ & 206 & $\mathrm{ARB}$ & Telmisartan & $\begin{array}{l}\text { ACE (I/D) } \\
\text { AGT (A-6G) } \\
\text { AT1 (A1166C, } \\
\text { C573T) }\end{array}$ & $\begin{array}{l}\text { No } \\
\text { No } \\
\text { No } \\
\text { No }\end{array}$ \\
\hline Yu et al. [33] & 2009 & China & $\begin{array}{l}\text { Chinese } \\
(100 \%)\end{array}$ & 509 & ACEI & $\begin{array}{r}\text { Imidapril or } \\
\text { benazepril }\end{array}$ & AT1 (A1166C) & No \\
\hline $\begin{array}{l}\text { Filigheddu et al. } \\
\text { [27] }\end{array}$ & 2008 & $\begin{array}{l}\text { Italy (North } \\
\text { Sardinia) }\end{array}$ & $\begin{array}{l}\text { White } \\
(100 \%)\end{array}$ & 191 & ACEI & Fosinopril & $\begin{array}{l}\text { ACE (I/D) } \\
\text { AGT (A-6G) } \\
\text { AT1 (A1166C) }\end{array}$ & $\begin{array}{l}\text { No } \\
\text { No } \\
\text { No }\end{array}$ \\
\hline Fan et al. [43] & 2007 & China & $\begin{array}{l}\text { Chinese } \\
(100 \%)\end{array}$ & 624 & ACEI & Captopril & ACE2 (rs2106809) & Yes \\
\hline $\begin{array}{l}\text { Brunner et al. } \\
{[34]}\end{array}$ & 2007 & USA & $\begin{array}{l}\text { White } \\
(35 \%) \\
\text { Hispanic } \\
(44 \%)\end{array}$ & 551 & ACEI & Trandolapril & AT1 (A1166C) & No \\
\hline Su et al. [32] & 2007 & $\begin{array}{l}\text { China } \\
\text { (Shanghai) }\end{array}$ & $\begin{array}{l}\text { Chinese } \\
(100 \%)\end{array}$ & 1,447 & ACEI & Benazepril & $\begin{array}{l}\text { AGT (multi loci) } \\
\text { AT1 (multi loci) } \\
\text { AT2 (multi loci) }\end{array}$ & $\begin{array}{l}\text { Yes } \\
\text { Yes } \\
\text { No }\end{array}$ \\
\hline Arnett et al. [28] & 2005 & USA & $\begin{array}{l}\text { White } \\
(61 \%) \\
\text { Black } \\
(35 \%)\end{array}$ & 7,528 & ACEI & Lisinopril & $\mathrm{ACE}(\mathrm{I} / \mathrm{D})$ & No \\
\hline Yu et al. [31] & 2005 & China & $\begin{array}{l}\text { Chinese } \\
(100 \%)\end{array}$ & 501 & ACEI & $\begin{array}{r}\text { Imidapril or } \\
\text { benazepril }\end{array}$ & AGT (M235T) & No \\
\hline Yu et al. [29] & 2003 & China & $\begin{array}{l}\text { Chinese } \\
(100 \%)\end{array}$ & 517 & ACEI & $\begin{array}{r}\text { Imidapril or } \\
\text { benazenril }\end{array}$ & $\mathrm{ACE}(\mathrm{I} / \mathrm{D})$ & No \\
\hline
\end{tabular}

$A R B$ angiotensin receptor blocker; $A C E$ angiotensin-converting enzyme, $A C E I$ ACE inhibitor; $A C E(I / D)$ insertion and deletion genetic variant of intron 16; $A G T$ angiotensinogen; $A T 1$ angiotensin II type 1 receptor; $A T 2$ angiotensin II type 2 receptor; $R E N$ renin

Again, however, Su et al. reported that individual SNPs including A1166C are not associated with the antihypertensive effects of benazepril but two haplotypes of AT1 $(\mathrm{H} 2, \mathrm{H} 3)$ are associated with blood pressure reduction in response to benazepril [32]. As this is the only report regarding the haplotypes of AT1, further evaluations are expected.

\section{AT2 Gene Variant}

AT2, a subtype of the angiotensin II receptor, which is thought to be expressed considerably less in adult tissues than AT1, functions as a vasodilator and has some antiproliferative effects against the AT1 receptor. From database research, we identified two studies about AT2: one is ours, using an ARB [25••], and the other is haplotype analysis with an ACE inhibitor [32]. As the AT2 gene is located on the $\mathrm{X}$ chromosome, the evaluation is a little complicated. In our study, we grouped the genotype by the presence or the absence of the A allele, and the other study evaluated haplotypes separately for males and females. No significant difference in blood pressure reduction was observed in these two studies. As these are the only two reports regarding AT2, further evaluations are expected. 


\section{REN Gene Variant}

In the whole body of the RAS, renin is the first step and the rate-limiting enzyme. The gene is supposed to play a major role in blood pressure regulation and in the response to RAS blockade interventions. However, REN has not been examined as a candidate for pharmacogenomics. To our knowledge, our study [25••] is the only one to report on the relationship between the genetic variants and blood pressure effects of RAS blockade with an adequate sample size. This study comprised 231 hypertensive patients, who were given 40 to $160 \mathrm{mg}$ per day of valsartan as monotherapy for 3 months. Changes in diastolic blood pressure differed significantly between genotypes of REN C-5312T: the reduction was $10.7 \mathrm{~mm} \mathrm{Hg}$ (from $95.9 \pm 12.9$ to $85.2 \pm 11.4$ ) in CC versus $7.0 \mathrm{~mm} \mathrm{Hg}$ reduction (from $94.7 \pm 14.0$ to $87.7 \pm 12.6$ ) in CT/ TT $(P=0.02$ for interactive effects of valsartan and genotype). Responder rates also differed between the genotypes: $72.8 \%$ in $\mathrm{CC}$ versus $58.0 \%$ in CT/TT $(P=0.03)$. Multiple logistic regression analysis revealed that $\mathrm{CC}$ homozygotes of REN C-5312T were an independent predictor for response, with an odds ratio of 2.03 (95\% CI, 1.10-3.74).

A plausible explanation is as follows: As shown in Fig. 1, our recent studies of the transcription mechanism of the human renin gene revealed that multiple trans-factors and cis-elements are involved in the transcriptional regulation [35-39]. A distal enhancer, a 225-bp region located $-5,777 /-5,552$ base upstream of the human renin gene, gave about 57-fold higher transcription rates [38]. REN C$5312 \mathrm{~T}$ of the human renin gene was discovered as a functional new polymorphism in this distal enhancer region [40]. The levels of transcription were $45 \%$ greater with the $5312 \mathrm{~T}$ variant than with the $5312 \mathrm{C}$ variant. Thus, the variant was validated as a functional SNP. The results of the study demonstrated that the homozygote of the $\mathrm{C}$ allele shows greater blood pressure reduction from ARBs than the $\mathrm{T}$ allele carrier and can be a predictor of response. One explanation may be that homozygotes of the $\mathrm{C}$ allele may have a lower level of tissue renin concentration and are more affected by the drug than $\mathrm{T}$ allele carriers. As this is the only report regarding REN, further evaluations are expected, especially to explore the RAS blockade response with different therapeutic combinations. The distinct effects on the RAS by target channel subtype, as shown for calcium channel blockers [41•], should be well considered.

\section{ACE2 Gene Variant}

ACE2, a newly emerging component of the reninangiotensin system (RAS), is presumed to be a counterregulator against $\mathrm{ACE}$ in degrading angiotensin II to angiotensin 1-7, which is thought to act as a vasodilator and to be involved in apoptosis and growth arrest [42]. Accordingly, ACE2 is also a plausible candidate for pharmacogenomic study for the RAS. To our knowledge, only the study by Fan et al. [43] has yet reported a relationship between genetic variants of ACE2 and blood pressure effects with RAS blockade. These authors reported that the adjusted diastolic blood pressure response to captopril in women was $3.3 \mathrm{~mm} \mathrm{Hg}$ lower in ACE2 rs2106809 T allele carriers than in CC genotype carriers $(P=$ 0.019). As this is the only report regarding ACE2, further evaluations are expected.

\section{Conclusions}

A previous well-documented review of this issue in 2007 [20] identified no consistent conclusions, but problems have been attributed to methodologic limitations such as race, patient selection, behavioral factors such as salt intake, combining of different therapies, drug dose, administration term and drug selection, statistical power, combining of different alleles, and end points such as definition of responders. We thought that one of the most important and fundamental concerns should be statistical power estimation. Considering practical clinical implications, the significant and adequate difference

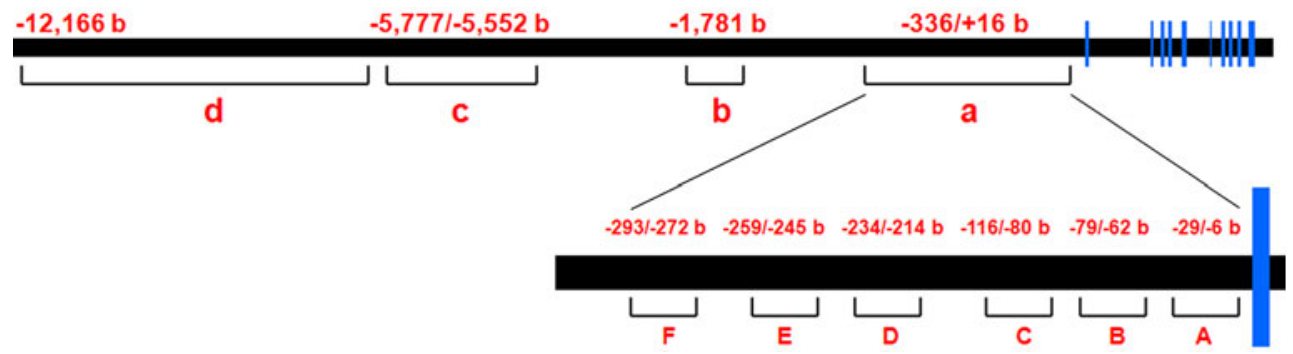

Fig. 1 Structure of transcriptional regulatory elements for the human renin gene. The horizontal bars represent alignment of the gene, and the vertical bars represent exons. Shown are a the proximal promoter; b the negative calcium response element (nCaRE); c the distal enhancer; $\mathbf{d}$ the tissue-specific expression-determining element; a Ets motif; b HOX-PBX motif; c no known consensus; d cAMP response element (CRE); e direct repeat (DR) motif; f AGE3-like site. (From Konoshita et al. [37], with permission of John Wiley and Sons.) 
is assumed to be about $5 \mathrm{~mm} \mathrm{Hg}$ in diastolic blood pressure. Thus, the needed minimum sample size was calculated to be about 200 subjects in total. By selecting studies with about 200 or more subjects, we tried to produce an updated statistical review, and we obtained relatively consistent results, concluding that the conventional genetic variants of the system - the ACE I/D, AGT M235T, AT1 A1166C, and AT2 variant-are not associated with the antihypertensive effects of RAS blockade, at least by individual SNPs. In contrast, significant associations have been reported with AGT rs7079, AT1 haplotype, REN, and ACE2, each in one report. For these variants, further evaluations are expected.

Disclosure No potential conflicts of interest relevant to this article were reported.

Open Access This article is distributed under the terms of the Creative Commons Attribution Noncommercial License which permits any noncommercial use, distribution, and reproduction in any medium, provided the original author(s) and source are credited.

\section{References}

Recently published papers of interest have been highlighted as

- Of importance

-. Of major importance

1. Corvol P, Soubrier F, Jeunemaitre X. Molecular genetics of the renin-angiotensin-aldosterone system in human hypertension. Pathol Biol (Paris). 1997;45(3):229-39.

2. Dzau V. The cardiovascular continuum and renin-angiotensinaldosterone system blockade. J Hypertens Suppl. 2005;23(1):S9 17.

3. Wakahara S, Konoshita T, Mizuno S, et al. Synergistic expression of angiotensin-converting enzyme (ACE) and ACE2 in human renal tissue and confounding effects of hypertension on the ACE to ACE2 ratio. Endocrinology. 2007;148(5):2453-7.

4. Konoshita T, Wakahara S, Mizuno S, et al. Tissue gene expression of renin-angiotensin system in human type 2 diabetic nephropathy. Diabetes Care. 2006;29(4):848-52.

5. Cambien F, Poirier O, Lecerf L, et al. Deletion polymorphism in the gene for angiotensin-converting enzyme is a potent risk factor for myocardial infarction. Nature. 1992;359(6396):641-4.

6. Baboolal K, Ravine D, Daniels J, et al. Association of the angiotensin I converting enzyme gene deletion polymorphism with early onset of ESRF in PKD1 adult polycystic kidney disease. Kidney Int. 1997;52(3):607-13.

7. Perez-Oller L, Torra R, Badenas C, et al. Influence of the ACE gene polymorphism in the progression of renal failure in autosomal dominant polycystic kidney disease. Am J Kidney Dis. 1999;34(2):273-8

8. Konoshita T, Miyagi K, Onoe $\mathrm{T}$, et al. Effect of ACE gene polymorphism on age at renal death in polycystic kidney disease in Japan. Am J Kidney Dis. 2001;37(1):113-8.
9. Parving HH, de Zeeuw D, Cooper ME, et al. ACE gene polymorphism and losartan treatment in type 2 diabetic patients with nephropathy. J Am Soc Nephrol. 2008;19(4):771-9.

10. Jeunemaitre X, Soubrier F, Kotelevtsev YV, et al. Molecular basis of human hypertension: role of angiotensinogen. Cell. 1992;71 (1):169-80.

11. Caulfield M, Lavender P, Farrall M, et al. Linkage of the angiotensinogen gene to essential hypertension [see comments]. N Engl J Med. 1994;330(23):1629-33.

12. Bonnardeaux A, Davies E, Jeunemaitre X, et al. Angiotensin II type 1 receptor gene polymorphisms in human essential hypertension. Hypertension. 1994;24(1):63-9.

13. Tiret L, Bonnardeaux A, Poirier O, et al. Synergistic effects of angiotensin-converting enzyme and angiotensin-II type 1 receptor gene polymorphisms on risk of myocardial infarction [see comments]. Lancet. 1994;344(8927):910-3.

14. Lewis EJ, Hunsicker LG, Clarke WR, et al. Renoprotective effect of the angiotensin-receptor antagonist irbesartan in patients with nephropathy due to type 2 diabetes. N Engl J Med. 2001;345 (12):851-60.

15. Brenner BM, Cooper ME, de Zeeuw D, et al. Effects of losartan on renal and cardiovascular outcomes in patients with type 2 diabetes and nephropathy. N Engl J Med. 2001;345(12):861-9.

16. Parving HH, Lehnert H, Brochner-Mortensen J, et al. The effect of irbesartan on the development of diabetic nephropathy in patients with type 2 diabetes. N Engl J Med. 2001;345(12):870-8.

17. Dahlof B, Devereux RB, Kjeldsen SE, et al. Cardiovascular morbidity and mortality in the Losartan Intervention For Endpoint reduction in hypertension study (LIFE): a randomised trial against atenolol. Lancet. 2002;359(9311):995-1003.

18. Julius S, Kjeldsen SE, Weber M, et al. Outcomes in hypertensive patients at high cardiovascular risk treated with regimens based on valsartan or amlodipine: the VALUE randomised trial. Lancet. 2004;363(9426):2022-31.

19. Julius S, Nesbitt SD, Egan BM, et al. Feasibility of treating prehypertension with an angiotensin-receptor blocker. $\mathrm{N}$ Engl $\mathrm{J}$ Med. 2006;354(16):1685-97.

20. Farahani P, Dolovich L, Levine M. Exploring design-related bias in clinical studies on receptor genetic polymorphism of hypertension. J Clin Epidemiol. 2007;60(1):1-7.

21. Rigat B, Hubert C, Alhenc-Gelas F, et al. An insertion/deletion polymorphism in the angiotensin I-converting enzyme gene accounting for half the variance of serum enzyme levels. J Clin Invest. 1990;86(4):1343-6.

22. Ueda S, Meredith PA, Morton JJ, et al. ACE (I/D) genotype as a predictor of the magnitude and duration of the response to an ACE inhibitor drug (enalaprilat) in humans. Circulation. 1998;98 (20):2148-53.

23. Kurland L, Melhus H, Karlsson J, et al. Angiotensin converting enzyme gene polymorphism predicts blood pressure response to angiotensin II receptor type 1 antagonist treatment in hypertensive patients. J Hypertens. 2001;19(10):1783-7.

24. •• Nordestgaard BG, Kontula K, Benn M, et al. Effect of ACE insertion/deletion and 12 other polymorphisms on clinical outcomes and response to treatment in the LIFE study. Pharmacogenet Genomics. 2010;20(2):77-85. Nordestgaard et al. demonstrated that ACE insertion/deletion and 12 other polymorphisms of hypertension susceptibility genes did not affect blood pressure reduction, in this pharmacogenomic study with conditions considerably better (especially in sample size, which was 1,774 for losartan) than those of previous studies.

25. • Konoshita T, Kato N, Fuchs S, et al. Genetic variant of the reninangiotensin system and diabetes influences blood pressure response to angiotensin receptor blockers. Diabetes Care. 2009;32(8):148590. The authors clarify the minimum and sufficient subject number for pharmacogenomic study of the RAS from a viewpoint of 
practical clinical implications, and for the first time they demonstrate that a genetic variant of REN C-5312 T contributes to the blood pressure response to ARBs and is a independent predictor for response. The authors also evaluated conventional genetic variants of the RAS (i.e., ACE I/D, AGT M235T, AT1 A1166C, and AT2 C3123A) and demonstrated no association with the blood pressure response. Further, the authors discussed and well validated the variant from their studies of the human renin gene transcription mechanism.

26. Redon J, Luque-Otero M, Martell N, Chaves FJ. Reninangiotensin system gene polymorphisms: relationship with blood pressure and microalbuminuria in telmisartan-treated hypertensive patients. Pharmacogenomics J. 2005;5(1):14-20.

27. Filigheddu F, Argiolas G, Bulla E, et al. Clinical variables, not RAAS polymorphisms, predict blood pressure response to ACE inhibitors in Sardinians. Pharmacogenomics. 2008;9(10):1419-27.

28. Arnett DK, Davis BR, Ford CE, et al. Pharmacogenetic association of the angiotensin-converting enzyme insertion/deletion polymorphism on blood pressure and cardiovascular risk in relation to antihypertensive treatment: the Genetics of Hypertension-Associated Treatment (GenHAT) study. Circulation. 2005;111(25):3374-83.

29. Yu H, Zhang Y, Liu G. Relationship between polymorphism of the angiotensin-converting enzyme gene and the response to angiotensin-converting enzyme inhibition in hypertensive patients. Hypertens Res. 2003;26(11):881-6.

30. Hingorani AD, Jia $\mathrm{H}$, Stevens PA, et al. Renin-angiotensin system gene polymorphisms influence blood pressure and the response to angiotensin converting enzyme inhibition. J Hypertens. 1995;13 (12 Pt 2):1602-9.

31. Yu H, Lin S, Liu G, et al. T1198C polymorphism of the angiotensinogen gene and antihypertensive response to angiotensinconverting enzyme inhibitors. Hypertens Res. 2005;28(12):981-6.

32. Su X, Lee L, Li X, et al. Association between angiotensinogen, angiotensin II receptor genes, and blood pressure response to an angiotensin-converting enzyme inhibitor. Circulation. 2007;115 (6):725-32.

33. Yu H, Lin S, Jin L, et al. Adenine/cytosine(1166) polymorphism of the angiotensin II type 1 receptor gene and the antihypertensive response to angiotensin-converting enzyme inhibitors. J Hypertens. 2009;27(11):2278-82.
34. Brunner M, Cooper-DeHoff RM, Gong Y, et al. Factors influencing blood pressure response to trandolapril add-on therapy in patients taking verapamil SR (from the International Verapamil SR/Trandolapril [INVEST] Study). Am J Cardiol. 2007;99(11):1549-54.

35. Konoshita T, Germain S, Philippe J, et al. Evidence that renal and chorionic tissues contain similar nuclear binding proteins that recognize the human renin promoter. Kidney Int. 1996;50 (5):1515-24.

36. Konoshita T, Makino Y, Wakahara S, et al. Candidate cis-elements for human renin gene expression in the promoter region. J Cell Biochem. 2004;93(2):327-36.

37. Konoshita T, Fuchs S, Makino Y, et al. A proximal direct repeat motif characterized as a negative regulatory element in the human renin gene. J Cell Biochem. 2007;102(4):1043-50.

38. Germain S, Bonnet F, Philippe J, et al. A novel distal enhancer confers chorionic expression on the human renin gene. J Biol Chem. 1998;273(39):25292-300.

39. Fuchs S, Germain S, Philippe J, et al. Expression of renin in large arteries outside the kidney revealed by human renin promoter/LacZ transgenic mouse. Am J Pathol. 2002;161(2):71725.

40. Fuchs S, Philippe J, Germain S, et al. Functionality of two new polymorphisms in the human renin gene enhancer region. J Hypertens. 2002;20(12):2391-8.

41. - Konoshita T, Makino Y, Kimura T, et al. A new-generation N/Ltype calcium channel blocker leads to less activation of the reninangiotensin system compared with conventional L type calcium channel blocker. J Hypertens. 2010;28(10):2156-60. The authors demonstrated that an N/L-type calcium channel blocker leads to less activation of the RAS than a conventional L-type calcium channel blocker. The result implies that for the elucidation of the $R A S$ blockade response with combined therapies, the distinct effects on the RAS of different drugs may affect results and should be carefully considered.

42. Boehm M, Nabel EG. Angiotensin-converting enzyme 2-a new cardiac regulator. N Engl J Med. 2002;347(22):1795-7.

43. Fan X, Wang Y, Sun K, et al. Polymorphisms of ACE2 gene are associated with essential hypertension and antihypertensive effects of Captopril in women. Clin Pharmacol Ther. 2007;82 (2):187-96. 